\title{
As raízes de uma planta que hoje é o Brasil: os índios e o Estado-Nação na era Vargas ${ }^{1}$ \\ Seth Garfield \\ Bowdoin College
}

\section{RESUMO}

Este artigo examina a construção do Índio por funcionários e intelectuais durante o Estado Novo (1937-1945) e os esforços de povos indígenas para empregar essas imagens. Funcionários do Estado - preocupados com unificação nacional, defesa territorial e configuração racial - sustentaram o Índio como um ícone que trouxe contribuições inestimáveis à formação histórica e cultural brasileira. O proto-patriota, entretanto, só pôde ser completamente redimido pela tutela governamental. Confrontados com um projeto estatal ambigüo, grupos indígenas deram várias respostas.

Palavras-chave: Índio; Nação; Cultura.

\begin{abstract}
This article looks at the construction of the Indian by government officials and intellectuals during the Estado Novo (1937-45), and the efforts of indigenous peoples to engage these images. State officials - concerned with national consolidation, territorial defense, and racial pedigree - upheld the Indian as na icon who had made invaluable contributions to Brazilian historical and cultural formation. The proto-patriot, however, could only be fully redeemed through government tutelage. Confronted by na ambiguos state project, indigenous groups demonstrated varied responses.

Keywords: Indian; Nation, Culture.
\end{abstract}


Este artigo analisa as construções culturais por meio das quais o Estado Novo (1937-1945) buscou dominar a população indígena. Propulsor no processo da integração nacional brasileira, o Estado Novo foi marcado pela centralização do poder federal, pela ampla intervenção estatal na economia e na sociedade e por um programa nacionalista. O exame do modo como funcionários do Estado e intelectuais criaram e disseminaram noções de indianidade, e de como os índios nelas se engajaram, abre uma perspectiva interessante sobre o processo de formação do Estado nesse momento crítico da história brasileira. Inspirado em The Great Arch de Philip Corrigan e Derek Sayer, este artigo repensa análises das relações entre o povo indígena e o Estado brasileiro.

Em seu estudo sobre a formação do Estado inglês como uma "revolução cultural", Corrigan e Sayer examinam o papel do Estado ao restringir o comportamento social e moldar a vida dos seus cidadãos. No entanto, como eles apontam, o poder do Estado não só restringe e reprime, como por vezes fortalece e capacita seus súditos². Nem o martírio descrito nas histónias institucionais, nem o plano magistral de um Estado Leviatã de análises revisionistas, a política indígena durante o Estado Novo delineia-se como um projeto ambigüo moldado porfatores históricos e atores sociais ${ }^{3}$. Os índios emergem não como cifras, mas como interlocutores sociais que seguem e/ou contestam a política estatal, criando novas possibilidades ${ }^{4}$.

\section{VARGAS E OS ÍNDIOS}

Em ago sto de 1940, o presidente Getúlio Vargas visitou a aldeia dos índios Karajá na Ilha do Bananal, no Brasil Central. Foi o primeiro presidente brasileiro a visitar uma área indígena, ou o O este da nação nesse sentido. Três anos antes ele havia dissolvido o Congresso e abolido todos os partidos políticos, proclamando um Estado Novo compromissado com o desenvolvimento e a integração nacional. Como parte de seu projeto multifacetado de construção de um Brasil novo - mais independente economicamente, mais integrado politicamente e socialmente mais unificado, Vargas voltou-se para o valor simbólico dos aborígenes. Diferentemente de "plantas exóticas"do liberalismo econômico e do Marxismo, os quais o regime autoritánio nacionalista procurou extirpar o solo brasileiro mediante repressão política, censura e intervenção federal em assuntos regionais, os índios seriam defendidos por Vargas por conterem as verdadeiras raízes da brasilidade.

Os Karajá, então sob a responsabilidade de um órgão federal, o Ser- 
viço de Proteção aos Índios (SPI), receberam a delegação presidencial com uma grande cerimônia. Eles apresentaram rituais "tradicionais" e cantaram o Hino Nacional diante da bandeira brasileira e Vargas, por sua vez, distribuiu facas, machadinhas e ferramentas para os índios. Consoante com sua imagem de "Pai dos Pobres", o presidente segurou um bebê Karajá nos braços. Depois de explorar a Ilha, Vargas manifestou o desejo de reconhecer o território dos "Xavante extremamente ferozes" que habitavam as redondezas. Da segurança de seu avião, Vargas viu, através de binóculos, uma aldeia Xavante não contactada. Encorajado por essa oposição potencial, o ilustre visitante esboçou seu plano para o Oeste. Vargas prometeu distribuir terras para os índios e caboclos que viviam na região. Ao "fixar o homem à terra", o Estado extirparia as raízes do nomadismo, convertendo índios e sertanejos em cidadãos produtivos. O SPI iria doutrinar os índios, "fazendo-os compreender a necessidade do trabalho".5.

A viagem de Vargas ao Centro-oeste, arquitetada para se assemelhar às ousadas expedições dos bandeirantes no período colonial, não foi na verdade uma aventura perigosa. As maravilhas da aeronáutica facilitaram 0 acesso a lugares antes inacessíveis ao centro do poder estatal. Além disso, o Departamento de Imprensa e Propaganda (DIP), encarregado de disseminar as diretrizes culturais e ideológicas do Estado Novo, assegurou uma viagem tranqüila. Um cinegrafista do DIP acompanhou Vargas, filmando imagens que o regime autoritánio nacionalista procurou to mar relíquias: índios vigorosos, emblemáticos da força inata dos nativos brasileiros; o "tradicionalismo" das comunidades indígenas; a camaradagem entre índios e brancos; a bonomia do presidente, epítome do homem cordial brasileiro; o longo braço do Estado estendendo-se ao sertão para darlhe assistência ${ }^{6}$.

Os índios, que representavam uma porcentagem minúscula da população brasileira situada predominantemente nas fronteiras remotas, foram de repente convocados para o palco da política. Diferentes fatores provocaram o seu aparecimento: o esforço do Estado Novo para consolidar o poder e redefinir o território nacional; e as preocupações da elite sobre as origens da nação e a composição racial da época. Tudo isso influenciaria uma formulação do Estado sobre a identidade cultural dos índios e uma política para a sua integração.

\section{A MARCHA PARA O OESTE E OS ÍNDIOS}

A redescoberta do índio fez parte da campanha governamental para popularizar a Marcha para o Oeste. Lançada na véspera de 1938, a Mar- 
cha para o Oeste foi um projeto dirigido pelo governo para ocupar e desenvolver o interior do Brasil. Nas palavras de Vargas, a Marcha incorporou "o verdadeiro sentido de brasilidade", uma solução para os infortúnios da nação. Apesar do extenso território, o Brasil havia prosperado quase que exclusivamente na região litoral, enquanto o vasto interior mantinha-se estagnado - vítima da política mercantilista colonial, da falta de estradas viáveis e de rios navegáveis, do liberalismo econômico e do sistema federalista que caracterizaram a Velha República (1889-1930). Mais de $90 \%$ da população brasileira ocupava cerca de um terço do território nacional. $\mathrm{O}$ vasto interior, principalmente as regiões Norte e Centro-oeste, permanecia esparsamente povoado. Muito índios, é claro, fugiram para o interior justamente por estas razões. Mas os seus dias de isolamento, anunciou o governo, estavam contados.

Sob os cuidados do governo federal, afirmavam funcionários do Estado Novo, o potencial do sertão não mais seria desperdiçado. A extração dos preciosos recursos naturais e humanos do sertão asseguraria a prosperidade da nação. Como observou Vargas, o Brasil não precisava olhar para além de seu próprio quintal esquecido, "vales férteis e vastos" e "entranhas da terra, ...de onde os instrumentos de nossa defesa e do nosso progresso industrial seriam forjados" $\mathrm{s}^{\prime \prime}$. Ao proporcionar escolas e serviços de saúde para índios e sertanejos, e redes de comunicação e transporte, o governo consolidaria a nação como um todo orgânico.

Vargas incorporou o Brasil central e sua população ao repertório ideológico de seu regime. O Estado havia arrumado o palco com pioneiros vigorosos e funcionários valoroso ${ }^{8}$. $\mathrm{O}$ espetáculo foi até acompanhado por música, variando desde uma composição de Villa-Lobos até uma canção carnavalesca, de 1939, Marcha para o Oeste9. Vargas era o personagem principal. Sem mesmo serem ouvidos, os índios receberam o papel de heróis - embora necessitassem de uma adaptação.

A campanha do regime Vargas para glamourisar o índio encontrou um ardente colaborador em Cândido Rondon. Primeiro diretor do SPI, estabelecido em 1910, Rondon entusiasmou-se com a atenção do Estado Novo para com os índios e seus "problemas". Após a revolução de 1930, quando as alocações do orçamento para o SPI foram reduzidas à metade, o órgão procurou cair nas boas graças do regime Vargas; em 1944, o orçamento anual do SPI era o segundo mais alto dos 35 anos de sua história $^{10}$. Prezando os índios e o seu valor ideológico para o Estado Novo, Vargas nomeou Rondon diretor do Conselho Nacional de Proteção aos Índios 
(CNPI), um órgão criado em 1939 para promover a conscientização pública sobre a cultura indígena e a política estatal ${ }^{11}$.

Num discurso intitulado Rumo ao Oeste, difundido pelo DIP em setembro de 1940, Rondon enalteceu as contribuições indígenas para a história brasileira, e o inestimável papel do Estado para a sua integração. Amigo, guerreiro, confidente e parceiro sexual, o índio deu assistência vital ao português em seu estabelecimento no Brasil, afirmou Rondon. "Eles nos deram a base do novo caráter nacional", exultou ele, "resistência, bravura, generosidade e honestidade trazidos pelo índio à formação do nosso povo, eis o que consideramos precioso, tanto no passado como ainda no presente ${ }^{\prime \prime 12}$.

Inventando tradições, Rondon omitiu a deslealdade do índio para com o português e minimizou atrocidades cometidas contra os índios ${ }^{13}$. Por exemplo, ele distorceu a narrativa da guerra dos portugueses contra os holandeses, ocorrida no século XVI no Nordeste. Ao citar relatos históricos, Rondon exaltou que índios e caboclos confrontaram não só os holandeses como também uma coroa portuguesa covarde, prestes a render-se e a entregar o sagrado território brasileiro. Apesar da insistência de Rondon de que "foi essa a primeira manifestação heróica da nossa existência nacional", o índio teve um papel muito mais complexo que o de proto-patriota durante a invasão holandesa. De fato, muitos índios ficaram ao lado dos holandeses e, com a derrota e a expulsão dos holandeses, lamentaram o seu abandono ${ }^{14}$. Estas verdades foram empurradas para debaixo do tapete pelo govemo: elas eram inapropriadas para a imagem do nobre selvagem e de uma nação que procurava pôr a casa em ordem.

Do ponto de vista de Rondon, "no conjunto de preciosidades com que nos deparamos nessa nova Marcha para o Oeste, todas elas relevan-

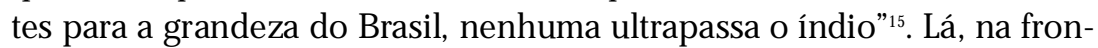
teira, o Brasil poderia beneficiar-se da essência cultural dos índios não contactados (e portanto incomuptos): paciência, fidalguia e orgulho. Para garantir a sobrevivência dos índios, o SPI demarcaria suas terras, tais como estabelecido pela Constituição Federal de 1937. Mas, como a cultura e identidade indígenas eram vistas como transitórias - um estágio evolutivo -, os lotes demarcados não seriam necessários para manter o seu modo de vida ${ }^{16}$. Rondon, positivista ortodoxo, junto com seus colegas ideólogos no SPI, acreditava no progresso inevitável das sociedades como evolução dos chamados estágios de primitivismo ao racionalismo científico ou "positivo".

Num futuro dourado, Rondon poderia antever "índios emancipa- 
dos", dividindo as terras de suas reservas em parcelas individuais, ou até residindo com não-índios nas colônias agrícolas que o governo estabeleceria como parte da Marcha para o Oeste. Os índios certamente deveriam ser integrados à sociedade brasileira; como declarou o SPI: "Não queremos que o índio permaneça índio. Nosso trabalho tem por destino sua incorporação à nacionalidade brasileira, tão íntima e completa quanto possível" ${ }^{\prime 1}$. A integração não beneficiaria apenas os índios, mas também a nação, que não poderia desperdiçar recurso tão valioso. Assim, Vicente de Paulo Vasconcelos, diretor do SPI em 1939, declarou:

É claro que os índios, assim como o negro, terão que desaparecer um dia entre nós, onde não formam 'quistos raciais' dissolvidos na massa branca cujo afluxo é continuo e esmagador; mas do que se trata é de impedir o desaparecimento anormal dos índios pela morte, de modo o que a sociedade brasileira, além da obrigação que tem de cuidar deles, possa receber em seu seio a preciosa e integral contribuição do sangue indígena de que carece para a constituição do tipo racial, tão apropriado ao meio, que aqui surgiui ${ }^{18}$.

\section{A PRODUÇÃO CULTURAL DA INDIANIDADE}

O Estado Novo representou a relação entre os índios e o Estado-nação numa ótica romântica. Em 1934, consagrando um ícone cultural, Vargas decretou que o dia 19 abril seria o Dia do Índio. Nos anos seguintes, o Dia do Índio ocasionou numerosos eventos culturais e cerimônias públicas. Numa verdadeira blitz, o Estado organizou exibições em museus, programas de rádio, discursos e filmes sobre o índio - tudo isso com assistência do DIP.

O conjunto de textos dos indianistas publicados nesta era de censura estatal revela o interesse intelectual pelo índio e o seu suporte tácito pelo Estado. No seu livro sobre o Oeste brasileiro, Agenor Couto de Magalhães aclamou o índio por auxiliar na "construção de uma grande nação, dando sangue e trabalho aos portugueses para a formação da raça

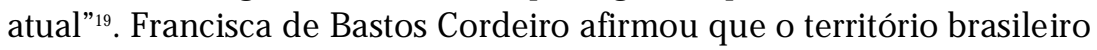
teria sido o verdadeiro local das civilizações antigas do Oriente Médio, e que os índios seriam descendentes das nações bíblicas ${ }^{20}$. Afonso Arinos de Mello Franco, o futuro ministro das Relações Exteriores, argumentou que os índios brasileiros, com suas sociedades igualitárias, contribuíram para o nascimento do liberalismo, sobre o qual os europeus agora alegavam a paternidade exclusiva ${ }^{21}$. 
Angyone Costa, professor de arqueologia, superou todos os seus pares com Indiologia, uma celebração do índio publicada em 1943. 0 índio, enfatizava Costa, forneceu aos brasileiros:

a mansidão, a delicadeza no trato, certa ironia que dispensamos às pessoas, a meiguice para os animais, a acuidade para todas as coisas. Veio-nos também a força no sofrimento, a ternura contemplativa pela terra, o apego excessivo às crianças, a sensibilidade com que envolvemos em nossa simpatia o mundo que nos cerca. ${ }^{22}$

Os atributos dos indígenas transmitiam também uma outra mensagem. Junto com a exibição dos índios, e não muito sutilmente, estavam a "benevolência" do regime de Vargas e a onipotência do SPI. O Estado iria "civilizar" índios que viviam no sertão remoto. A exibição de fotografias e documentos traziam à luz a aculturação dos índios sob a direção do SPI ${ }^{23}$. Reificando o Estado-nação, os funcionários do governo brasileiro representavam uma entidade consolidada, na qual os índios seriam integrados $^{24}$. De fato, o cenário era muito mais complexo: os esforços para integrar o índio faziam parte do processo de consolidação do Estado um processo, veremos adiante, no qual os próprios povos indígenas tiveram um papel formativo.

\section{O RETORNO DO NATIVO}

Restam, no entanto, algumas questões relativas à celebração do índio pelo Estado. Por que as elites construíram a imagem do índio desta maneira?A que propósito servia a retónica enaltecedora da contribuição indígena para o "caráter nacio nal"?Ao analisar-se a propaganda governamental, percebe-se que, apesar das narrações românticas sobre o passado e das visõ es utópicas sobre o futuro, o Estado Novo construiu a imagem do índio a partir de preocupações do momento.

A paixão do Brasil pelo índio na era Vargas fez parte de um movimento continental de expansão do interesse pela cultura indígena e pelas políticas indigenistas. O Dia do Índio, por exemplo, foi promovido no Congresso de Pátzcuaro em 1940, reunião internacional patrocinada pelo governo mexicano que tinha por meta desenvolver a compreensão cultural dos povos indígenas e projetos para a sua integração. Mas, se o México liderou o movimento indigenista continental, sobretudo com a organização do Instituto Indigenista Interamericano , este movimento também encontrou adeptos no Brasil ${ }^{25}$. De fato, o imponente monumento do líder 
asteca Cuauhtémoc, dado pelo governo mexicano à cidade do Rio de Janeiro, veio a inspirar as festividades brasileiras do Dia do Índio.

Os índios, assim denominados por força da crença européia de que eram asiáticos, agora eram celebrad os por sua americanidade. De fato, Zoroastro Artiaga, diretor do Museu Histórico de Goiás, afirmou em seu livro que o índio brasileiro originou-se na América do Sul, e não na Ásia ${ }^{26}$. Oswaldo Aranha, ministro das relações exteriores, aclamou "o herói anônimo, histórico, indígena, ou cósmico, filho valente do Mundo Novo”27. Artigos de jornal saudavam o índio desde "Yukon até a Patagônia"28. No seu discurso no Dia do Índio de 1944, Rondon censurou os antigos colonizadores europeus pela exploração da população indígena ${ }^{29}$.

Ao difamar o europeu e consagrar o indígena, os ideólogos e intelectuais brasileiros da Era Vargas inverteram ou subverteram a concepção eurocêntrica da história da cultura e do destino nacional, vigente na elite brasileira. A essência da brasilidade havia sido redefinida por membros da elite e da intelligentsia : ela não atravessou mais o Atlântico, mas brotou do solo da nação, da sua fauna, flora e de seus primeiros habitantes.

Esta tática não era nova. No século XIX, José de Alencar e Gonçalves Dias celebraram o nascimento de uma cultura brasileira própria, com narrativas altamente romantizadas dos índios ${ }^{30}$. Mais recentemente, na seqüência da Semana de Arte Moderna de 1922, em São Paulo, o poeta modernista Oswald de Andrade abraçou simbolicamente a cultura indígena com o Manifesto Antropofágico (1928), criticando a imitação de estilos europeus na arte brasileira e endossando a síntese do autóctone e do estrangeiro ${ }^{31}$. Embora afastados de Andrade, intelectuais do movimento de direita Verdeamarelo, tais como Plínio Salgado, Menotti del Picchia e Cas siano Ricardo, rejeitaram os europeus completamente; ao mesmo tempo em seus textos nacionalistas que glo rificavam o passado anterior ao descobrimento, endossavam o estudo da língua Tupi e defendiam o índio como símbolo nacional ${ }^{32}$. No início dos anos 30, Gilberto Freyre louvou a contribuição indígena para a formação da cultura brasileira ${ }^{33}$. Deste modo, os intelectuais da era Vargas podiam se apropriar de uma rica tradição brasileira de homenagem aos índios ${ }^{34}$.

No entanto, não só os motivos, como também o tom e o timbre destas homenagens aos índios variaram com o tempo. Se, por exemplo, o nativismo do século XIX teve como meta a separação de Portugal e a literatura romântica serviu para camuflar a instituição da escravidão africana, sob o regime Vargas a retórica indigenista transmitiu outras mensagens. Durante o Estado Novo, o Estado orquestrou ou promoveu um 
discurso indigenista que ecoava todas as questões proeminentes na política mundial da época: racismo, xenofobia e chauvinismo.

Numa época de crise econômica mundial e nacionalismo exacerbado, os brasileiros foram criticados por admirarem ideologias estrangeiras. O marxismo e o liberalismo, afirmavam os funcionários do Estado Novo, eram inapropriados às realidades nacionais. $\mathrm{O}$ mesmo valia para as teorias européias de superioridade racial, as quais eram criticadas por provocar ultraje - para não mencionar desconforto, uma vez que muitas famílias influentes careciam de ascendência puramente branca. Como Angyone Costa ironizava, apesar das deferências e pretensões da elite, todos os brasileiros eram considerados pelos europeus como "povo situado pouco acima dos negróides, abaixo dos amarelos e infinitamente distanciados dos brancos". Costa, portanto, convocava a nação para valorizar suas raízes indígenas:

Nós não chegaremos a ser um grande país, realmente com espírito e formação nacional próprios, se não nos orientarmos, social e politicamente, fora dos moldes alheios, numa firme diretriz americana, com o sentido de amor à terra, de compreensão e valorização do índio, seu legítimo dono ${ }^{35}$.

No entanto, Costa e sua coorte ideológica continuavam a antiga prática das elites brasileiras de pensar com "modelos externos" a realidade doméstica ${ }^{36}$. O Estado Novo, apesar de proclamar autenticidade própria, fez exatamente o oposto, ao adotar amplamente um modelo corporativista europeu em seus esforços para reordenar a sociedade brasileira. No seu discurso sobre a raça, o regime de Vargas também difundiu doutrinas européias, mas redefinindo os grupos considerados indesejáveis.

Com sua esmagadora população inter-racial, o Brasil não poderia abraçar com credibilidade uma ideologia que depreciasse todos os nãoeuropeus. Os brasileiros não-brancos deveriam não só ser defendidos mas aceito ${ }^{37}$. O SPI afirmava que, ao se falar de raça, "inferior" era sinônimo de "atrasado", substituindo assim a noção de inferioridade racial inerente pela de aperfeiçoamento racial ${ }^{38}$. Defendendo a estirpe do índio brasileiro, o SPI apontou: "A alma indígena está sujeita às mesmas paixões a que está sujeita a alma européia, mostrando, porém, superioridade na temperança, na energia paciente e até, digamos a verdade, na justiça e na caridade" ${ }^{\prime 39}$.

Se alguém menosprezasse a mistura racial no Brasil, o antropólogo Roquette-Pinto contestava: 
Para contradizer a opinião daqueles que crêem na má influência do cruzamento sobre a vitalidade da raça, devemos apontar, entre muitos outros exemplos, a população do nordeste do Brasil (Ceará, etc.) que é a região de grandes e fortes famílias de homens corajosos e ativos, conquistadores das florestas da Amazônia, quase todas com algum sangue índio e branco ${ }^{40}$.

Além disso, para que estes argumentos dissipassem os temores sobre a composição racial e a coesão social do Brasil, e as elites pudessem renovar sua antiga crença no "branqueamento" do índio, as políticas do SPI sustentaram a quimera de que integração e miscigenação, um dia iriam finalmente chegar. O obstáculo ao progresso nacional se escondia, ao invés, no "imigrante inassimilável", que residia (ou tentava residir) no Brasil, deterio rando sua harmo nia racial ${ }^{41}$. $O$ índio, entretanto, desde a conquista portuguesa, fortificara a nação brasileira através de alianças sexuais e militares.

\section{O ÍNDIO COMO SENTINELA}

Conquista e fortificação foram temas que preocuparam os brasileiros durante a época turbulenta da Segunda Guerra Mundial. A guerra, na qual o Brasil entrou formalmente em 1942, proporcionou um constante pano de fundo para as imagens projetadas do índio. A conquista portuguesa foi reexaminada à luz das últimas ameaças européias à soberania nacional. Sempre fiéis ao Brasil, os índios mais uma vez estavam provando seu patriotismo, contribuindo para os esforços de guerra através da produção agrícola e de borracha ${ }^{42}$. A retórica do governo sublinhava que, dado o amor do índio a seu território, seu amor ao Brasil seria uma "simples extensão ${ }^{43}$ ".

Numa época em que o governo falava no crescimento da nação determinado pela proporção de homens saudáveis "dotados de maior energia", o índio representava um patrimônio ${ }^{44}$. Os tributos ao índio louvavam sua "higidez física, comparável à beleza masculina dos helenos das olimpíadas" ${ }^{\prime 4}$. Quem poderia proteger melhor as fronteiras desprotegidas e "espaços vitais" das "nações cobiçosas" que buscavam um depósito para seus "excessos de população" do que o índio ${ }^{46}$ ? Rondon, orgulhoso da força e patriotismo indígena, endossou o serviço militar para os índios ${ }^{47}$. Além disso, a incorporação na sociedade brasileira evitaria a possibilidade de que "seja nossa população indígena atraída para os países limítrofes"48. $\mathrm{O}$ medo de uma quinta coluna indígena - de atração para "países limítrofes" -, demonstrou que por todo seu simbolismo nacionalista, os índios apre- 
sentavam um problema complicado também para as elites. Os índios, como primeiros habitantes do Brasil, desafiavam as instituições e tradiçõ es do Estado-nação. Apresentavam uma alternativa às leis brasileiras e ao sistema sócio-econômico - em suma, a tudo em que a legitimidade do governo se apoiava ${ }^{49}$. Ao heroicizar o índio, o Estado Novo buscou camuflar este conflito que sugeria não ser a lealdade indígena inata nem iminente.

Nem todos os funcionários do governo escondiam suas apreensões. Na posição de oficial do exército perto da fronteira ocidental, o Coronel Themístocles Paes de Souza Brasil concluía sobre o índio:

Nada produz, nem suficiente para o próprio conforto, é nômade, não obedece a leis e nem deles tem conhecimento, não tem a noção de Pátria... tem o cérebro pouco evoluído, não estando em condições satisfactórias para assimilar de modo completo a educação e as outras exigências da nossa civilização ${ }^{50}$.

Do mesmo modo, Ildefonso Escobar, um antigo membro do Conselho Nacional de Geografia, via o índio como um peso morto para a nação. Após quatro séculos, denunciou Escobar, os índios permaneciam "ingênuos e contemplando a natureza enquanto todos os outros brasileiros trabalhavam para o progresso da nação" ${ }^{{ }_{51}}$.

\section{DEFENDENDO O NOBRE SELVAGEM}

A figura do selvagem ignóbil e de sua contraparte nobre tinha raízes profundas que se vinculavam à conquista européia, durante o período colonial e no século XIX ${ }^{52}$. Esta dicotomia se originou da ambivalência européia para com as suas próprias sociedades, ambivalência esta que foi projetada nas populações indígenas. As várias respostas dos povos indígenas em relação aos europeus foi um outro fator que contribuiu para esta dicotomia ${ }^{53}$. Ambas as imagens, de fato, continuavam a ter credibilidade entre a população brasileira. Assim, ao construir sua imagem do índio como cidadão brasileiro primevo, o regime Vargas selecionou uma das várias imagens existentes ${ }^{54}$. Mas como, então, poderia o Estado rebater as acusações feitas contra o selvagem ignóbil, cujo comportamento, em séculos anteriores, teria justificado uma "guerra justa"55?

Quando o SPI reconheceu "a ferocidade dos nossos índios", como os Xavante, ele culpou os civilizados por provocarem a agressão dos índios. Por natureza "mansos e afáveis", os índios não puderam tolerar o que "em sua compreensão constituía uma afronta ou falta de respeito" 
Tal ponto de vista protegia a imagem consagrada do bom selvagem. No entanto, também furtava ao índio seu papel histórico, despindo-o das diretrizes sociais complexas e agendas políticas que marcaram sua interação com o mundo branco. Além disso, o modelo de relações interétnicas do Estado sugeria que, assim como a malevolência branca poderia desfigurar as sociedades indígenas, a benevolência branca poderia surtir o efeito contrário.

O governo, afinal, deu uma grande tarefa aos índios: tornar o interior produtivo, impedir as tramas imperialistas e garantir a "formação étnica" do Brasil. Para assistir os índios, o Estado iria ampliar para o sertão a rede de transporte, a saúde pública e educação para o sertão. Outros "problemas" tais como nomadismo, falta de disciplina no trabalho e a ausência de sentimento cívico seriam também remediados pelo governo.

\section{O DUPLO LEGADO DE VARGAS}

Os defensores do governo Vargas aplaudiram a sua iniciativa de redimir os desfavorecidos rurais. Finalmente, os índios - "os modestos mas dedicados trabalhadores da floresta, a verdadeira sentinela da fronteira, os vigilantes soldado s da nação" - seriam incorporados definitivamente como trabalhadores para a glória nacional ${ }^{57}$. O govemo federal exaltou 0 diretor do SPI José Maria de Paula em 1944 e prenunciou uma era promissora para os índios ${ }^{58}$.

Esta linguagem protecionista refletiu a tendência do Estado Novo de outorgar noções de cidadania e de direitos aos grupos sociais previamente marginalizados ${ }^{59}$. De fato, o abraço simbólico do índio pelo Estado Novo acabou por sufocá-lo. Esmagados pela retórica do governo, os índios teriam de lutar para expressar seus próprios pontos de vista em relação a sua terra, comunidade, cultura e história.

Sob Vargas, o Estado continuou a cultivar uma relação com os grupos indígenas fundamentada na legislação ditada décadas antes. O Código Civil de 1916 definiu os índios como "relativamente incapazes" em relação a questões civis. Em 1928, eles foram colocados sob um sistema de tutela federal, administrado pelo SPI. Em teoria, a tutela se destinava a proteger os grupos indígenas - muitas vezes despreparados ou não familiarizados com o sistema sócio-econômico brasileiro - da exploração. Quando o SPI defendia comunidades indígenas, como João Pacheco de Oliveira ilustra na sua etnografia sobre os Ticuna, os índios se beneficiavam e valorizavam a assistência governamental ${ }^{60}$. Neste mesmo espírito de boa vontade, o regime Vargas enobrecia os seus tutelados, dotando 
de prestígio cultural os grupos indígenas ao consagrá-los como os primeiros brasileiros.

Mas, ao mesmo tempo, a tutela e outras políticas paternalistas endossadas pelo regime Vargas possibilitavam o abuso e a repressão pelo Estado. O sistema de tutela permitiria o descuido sistemático dos interesses indígenas; políticas foram implementadas pelo Estado sem consulta aos grupos indígenas, considerados incompetentes para cuidar de seus próprios assuntos. Como o SPI pronunciava em 1939: "O índio, dado seu estado mental, é como uma grande criança que precisa ser educada"61. Os esforços para disciplinar a força de trabalho e eliminar o nomadismo disfarçados em temas de redenção - exemplificavam este tratamento autoritário; nesse sentido o Estado procurou redesenhar as fronteiras do território indígena com a Marcha para o Oeste.

Embora aproximadamente duzentos grupos diferentes vivessem no Brasil com diversas culturas, línguas e relações com a sociedade brasileira, o Estado reduziu-os todos a "índios", uma construção cultural que incorporou objetivos e idéias dos brancos. Rica em seu valor simbólico, a invenção estadonovista do índio contradizia as realidades atuais e passadas dos índios. Além do mais, os objetivos quixotescos e as instituições governamentais seriam sistematicamente lesados pela corrupção burocrática, pela oposição da elite e pela resistência indígena. Não obstante, os índios, junto com o governo e seus críticos, teriam de lidar com as imagens e políticas ambígüas popularizadas na era Vargasdurante muito tempo.

No entanto, desde o início da Marcha para o Oeste, grupos indígenas engajaram-se num projeto do Estado que tentava programar seu destino. Alguns índios rejeitaram totalmente a política governamental. Outros colaboraram com os esforços do Estado para "civilizar" a fronteira, aliando-se ao s funcionários do SPI, que lhes ofereciam a promessa de uma vida melhor. Contudo, outros abraçaram a retórica indigenista do Estado Novo, apesar de criticarem a atuação do Estado e de proporem alternativas. De fato, a variedade das respostas indígenas demonstra, como apontou William Roseberry, que a hegemonia cria não uma ideologia partilhada, mas uma matéria-prima comum e uma estrutura significativa para lidar e atuar diante das ordens sociais caracterizadas pela dominação ${ }^{62}$.

\section{Os XAVANTE E A MARCHA PARA O OESTE}

Em 1941, um ano após Vargas ter sobrevoado a área dos "Xavante extremamente ferozes", uma equipe de "pacificação" do SPI partiu para contactar os índios. Os Xavante não seriam uma audiência fácil de con- 
vencer. Em primeiro lugar, eles se autodenominavam A'uwe, que em sua língua Gê significa "as pessoas". Outros grupos não poderiam aspirar tal humanidade; o etnocentrismo do governo brasileiro encontrara seu par. Além do mais, os Xavante tinham dolorosas recordações da dominação branca. Quando os bandeirantes aventureiros começaram a penetrar Goiás em busca de ouro, no século XVIII, os A'uwe se tornaram alvo de ataque militares, caçadores de escravos, ataques de colonizadores e projetos de aldeamento. As guerras, doenças, migrações e aldeamentos desagregaram as comunidades A'uwe ${ }^{63}$. Por volta de 1840, segundo David MayburyLewis, aconteceu uma cisão definitiva. Um grupo, que se tornaria conhecido como Xerente, estabeleceu-se perto do rio Tocantins, onde manteria contacto contínuo com o mundo branco. Outro grupo, hoje conhecido como Xavante, fugiu de Goiás para Mato Grosso, atravessando o rio Araguaia para escapar de exploração dos colonos ${ }^{64}$.

Os Xavante apropriaram-se de um extenso território do norte do Mato Grosso. Por quase um século, difundiram o terror na região, amendrontando garimpeiros, fazendeiros e outros índios que invadissem seu território ${ }^{65}$. Com a Marcha para o Oeste, a necessidade de contactar ou "pacificar" os Xavante tornou-se urgente. Bem no centro do território brasileiro existia um grupo indígena hostil, sem sentimento cívico ou ética de trabalho "apropriada", alheio à língua portuguesa, impedindo a expansão e o desenvolvimento econômico do Oeste. Lá, no cerrado impenetrável, também se encontrava um valioso recurso humano. Por seu valor, os Xavante incorporavam o ideal das elites de uma essência indígena com suas contribuições potenciais para o então chamado caráter nacional brasileiro. Como afirmava um jornal: "Os Xavantes são os grandes índios do Brasil, os índios realmente representativos, os índios que deveriam ser eleitos como o símbolo da raça nativa - ao invés da criação romântica de José de Alencar"66.

Genésio Pimentel Barbosa liderou a expedição do SPI que estabeleceu um "posto de atração" próximo a uma aldeia Xavante no Rio das Mortes. A equipe do SPI, que consistia de cinco brancos e três índios, incluindo dois Xerente recrutados para servir de tradutores, ofereceu roupas, ferramentas e outras bugigangas como proposta de paz, marcando o início da assistência estatal ${ }^{67}$. Os Xavante, no entanto, desconsideraram 0 discurso nacionalista de Vargas. Em novembro de 1941, assassinaram Pimentel Barbosa e cinco de seus assistentes a bordunadas. Os tradutores Xerente e outros membros da equipe, que se encontravam fora do acam- 
pamento no momento do ataque, encontraram seus companheiros mortos $^{68}$. Os corpos ensangüentados de seus companheiros serviram de testemunhas da resposta dos Xavante; eles não desejavam ser colocados em pedestais nem reconstruídos pelo Estado.

A Marcha para o Oeste encontrara um obstáculo e o governo correu para mascarar a rejeição dos Xavante. Preservando a imagem do índio como bom selvagem e patriota inato, Cândido Rondon declarou: "O índio é uma criatura dócil de inteligência primária que só necessita de meios brandos para se render aos nossos apelos. Só posso, por isso, atribuir, o gesto impensado dos Xavante a alguma represália"69. O "gesto impensado" de fato, formou parte de um complicado universo nunca investigado com seriedade pelo governo: a cultura indígena. A estratégia Xavante de ataques surpresa manteve invasores à distância durante décadas. A defesa de extenso território foi essencial para manter sua economia mista baseada na caça e coleta e, em menor escala, na agricultura. Embora o governo Vargas retratasse o Oeste como uma utopia, os Xavante conheciam a variabilidade do clima e a pobreza do solo da região, que faziam da agricultura um empreendimento arriscado ${ }^{70}$. Por requisitar um extenso território para a caça de animais e coleta de frutas, babaçu e raízes, a comunidade Xavante combatia qualquer invasor que ameaçasse acesso ao precioso recurso natural.

Além disso, do ponto de vista dos índios, a importância de tal demonstração de força, longe de ser um "gesto impensado", estendia-se para além do campo de batalha. A força física, valorizada entre os jovens Xavante, definia masculinidade e posição social. Tal como a caça, a expressão mais comum de virilidade, a guerra requeria resistência e agilidade. Apesar de os homens Xavante orgulharem-se de sua força física - validando as homenagens do Estado Novo à força "natural" dos índios brasileiros - dificilmente aspiravam ser sentinelas da fronteira. A exibição pública de masculinidade serviu para reforçar as divisões de gênero e hierarquia de idade que estruturava a ordem social Xavante.

Devido às suas diretrizes sociais, orientação cultural e memória histórica, o amor dos Xavante pelo Brasil apenas podia ser "uma simples extensão" do amor que sentiam pelo seu território. A aldeia Xavante no Rio das Mortes não seria "pacificada" até cinco anos mais tarde - quando um grupo do SPI mais equipado, abençoado pelo suporte aéreo, retornou à região. 


\section{"Todos os ÍNDIOS ESTÃO A SERVIÇO DO BRASIL"}

Nem todos os grupos indígenas, no entanto, gozavam da autonomia que permitiu aos Xavante rejeitar a oferta do governo. Os índios explorados por fazendeiros, barões da borracha, contratadores de mão-de-obra, missionários ou por outros grupos indígenas não poderiam aspirar a tal teimosia. De fato, os Karajá talvez não tivessem se voltado tão impetuosamente para Vargas se não estivessem cada vez mais rodeados por brancos e atacados por seus inimigos mortais - os Xavante. Do mesmo modo, embora não saibamos as motivações pessoais que impeliram alguns Xerente a colaborar na "pacificação" dos Xavante, conhecemos os problemas sócio-econômicos que atingiam suas comunidades na época. Quando Curt Nimuendaju realizou sua pesquisa etnográfica entre os Xerente, em 1937, encontrou um grupo indígena rodeado por colonos brancos. A aldeia nativa, ela observou, tinha se to mado "um local de escassez" e os Xerente deixaram de trabalhar, exercendo a mendicância e roubando dos brancos ${ }^{71}$. A Marcha para o Oeste, no entanto, ofereceu a alguns Xerente a oportunidade de emprego e aventura no SPI e o glamour de contactar seus famosos parentes distanciados numa grande campanha patriótica.

O Estado Novo, com suas promessas de longo alcance de proteção e assistência estatal, oferecia um raio de esperança para vidas precárias como as do Xerente e Karajá. Há muito vistos como "brutos" pelos seus vizinhos "civilizados", os índios ago ra podiam se orgulhar de serem os primeiros brasileiros, além de antever novos aliados na sua luta. Podiam até se dirigir ao presidente da nação, que havia demonstrado tanto interesse pessoal em seus problemas. Em setembro de 1945, Lúno Arlindo do Valle, um índio Tembé, fez exatamente isso. Em uma carta de dez páginas para Vargas, Valle agradeceu o presidente pela "promessa feita aos índios do Brasil" e narrou o sofrimento dos índios nas mãos dos fazendeiros no Pará, seu estado natal. Valle escreveu, no entanto, não somente para expressar gratidão, mas para se autopromover: ele desejava ser nomeado inspetor do SPI do Pará, cargo então ocupado por um funcionário branco. Na sua tentativa de mobilizar apoio do chefe da nação, a carta nos revela uma fascinante perspectiva sobre o papel do índio no processo da formação do Estado brasileiro. Mesmo não sendo amplamente representativo de todos os povos ou comunidades indígenas, este texto merece uma análise mais minuciosa, uma vez que evidências escritas pelos índios documentando sua resposta ao Estado Novo e à Marcha para o Oeste são extremamente fragmentárias.

Nascido em 1895 numa aldeia Tembé, de mãe indígena e pai desco- 
nhecido, Valle estudou quando jovem num seminário católico em Belém. Em 1911, um inspetor do recém fundado SPI recrutou Valle para o escritório do Pará. Desestimulado pela falta de pagamento, ele abandonou seu trabalho, retomou os estudos e passou um breve período na Marinha. Ao retomar ao SPI em 1934, foi nomeado para um posto entre os índios Anaubé, no Rio Carari, mas trabalhou "sem conforto, sem a proteção do SPI e nada ganhando". Em 1941, Valle foi nomeado delegado do SPI na região de Moju, no Pará72. Em 1945, viajou para o Rio de Janeiro para participar do movimento queremista, o grande movimento popular em apoio à candidatura de Vargas nas próximas eleições. Em sua peregrinação para a capital, Valle passou pelo estado de Minas Gerais, pedindo apoio para Vargas e popularizando a causa indígena. Para dar provas de suas últimas campanhas pelo presidente, Valle incluiu depoimentos dos políticos locais.

Aristide Sousa Torres, um funcionário da cidade mineira de Conde Lafaiete, afirmou que em abril de 1945, Valle entreteve um sindicato com canções e costumes indígenas e agradeceu o cuidado e a proteção dispensados pelo Estado Novo para com os trabalhadores, índios e crianças. Neste mesmo mês, o auto-nomeado porta-voz indígena discursou em Barbacena, cujo prefeito elogiou o "cacique Lirio do Valle, [que] demonstrou ser um grande patriota e amante do crescente desenvolvimento de nossa querida Pátria”.

No seu apelo a Vargas, Valle articulou idéias que devem ter agradado os habitantes de Minas Gerais. Ele ressuscitou Poti - um guerreiro Potiguara que resistiu à invasão holandesa no século XVII - uma inspiração para todos os índios e brasileiros "que amam a liberdade e sabem lutar por ela"73. Prometeu integrar os índios e fazê-los cidadãos brasileiros "respeitáveis". Finalmente, Valle abraçou a imagem do índio genérico, o que buscava parceria com os brasileiros: "Sou um índio conhecedor de todos os costumes dos índios do Brasil e falo o idioma oficial entre eles, e todos os dialetos de suas tribos". Apesar de suas pretensões antropológicas, é improvável que Valle conhecesse "todos os costumes" de aproximadamente 200 grupos indígenas. Nem é provável que seu talento lingüístico o capacitasse a falar todos os seus dialetos. O que Valle certamente conhecia, baseado nas suas declarações, eram os costumes dos funcionários brancos. Assim como os propagandistas do Estado Novo, Valle não fez distinções entre grupos indígenas. Articulou uma narrativa européia da história indígena, começando com a conquista portuguesa, enriquecida por índios mitificados e focalisou a contribuição indígena para o "caráter nacional" do Brasil. A afirmação de Valle de que "nós índios 
somos a raiz de uma planta que hoje é o Brasil" e sua promessa de que "os índios estão de pé pelo Brasil" parece ter sido escrita por um ideólogo do DIP.

\section{REINTERPRETANDO O ÍNDIO E O ESTADO-NAÇÃO}

Como podemos entender a relação entre os índios e o Estado Novo? As narrativas celebratórias da política indigenista brasileira podiam saudar a assistência e a redenção proporcionada pelo Estado aos povos indígenas, tais como os Karajá e os Xerente. Os revisionistas, por outro lado, podem denunciar o projeto hegemônico do Estado em relação aos Xavante e seus efeitos sobre o comportamento e a identidade de índios como Valle. Para nos deslocarmos para além desta dicotomia - na qual o Estado substituiu o índio como a síntese tanto do bem como do mal - devemos não só reconhecer a ambigüidade do projeto estatal como também prestar mais atenção à variedade e às nuances da reação indígena ao poder do Estado. Assim como os Xavante rejeitaram o governo Vargas, os Karajá, Xerente e Tembé ajudaram a reforçá-lo. No entanto, mesmo enquanto representavam o papel que lhes foi designado, alguns grupos indígenas procuraram editar o script. De fato, um exame mais detalhado da carta de Valle revela como alguns índios promoveram o projeto estatal, ao mesmo tempo em que buscavam emendar o seu formato.

Os anos de trabalho sem pagamento e recursos adequados no SPI levaram Valle a criticar não a missão do Estado de proteger e integrar os índios, mas seu modus operandi. O tradicionalismo indígena não arruinou o seu trabalho nos postos do SPI, afirmou, mas sim a corrupção dos oficiais do SPI, que roubavam as verbas alocadas. Além do mais, Valle denunciou o racismo no SPI: "o SPI ultimamente não se enteressa [sic] pelos índios, por que lá só trabalham brancos e os brancos não se enteressa [sic] pelos índios". Na agência estatal remodelada por Valle, os índios iriam ocupar cargos superiores. Com Valle no comando e outros "índios competentes e civilizados" responsáveis pela diretoria, a verdadeira integração dos povos indígenas poderia ocorrer. Voltando à fábula de Poti, Valle o imbuiu de novo simbolismo. Poti ainda vivia nas comunidades indígenas na sua luta para repelir não só o estrangeiro, mas o "envasores [sic] brancos do SPI, brancos desonestos".

O discurso de Valle revela como os índios brasileiros, com outros grupos subaltemos, tanto apropriaram-se dos símbolos dominantes como os desafiaram ${ }^{74}$. Ao celebrar a proteção do governo aos povos indígenas, Valle difundiu as noções elaboradas pela elite sobre um caráter es- 
sencialmente indígena, um ícone proto-patriota cultural. $\mathrm{O}$ ataque Xavante confirmara que nem todos os índios viam Vargas como seu salvador nem o Brasil como sua pátria. No entanto, a elaboração de Valle, mediada pela sua experiência pessoal, não era de modo algum acrítica. A corrupção e o racismo dos funcionários do SPI coloriram as percepções de Valle sobre o governo, galvanizando sua exigência por um órgão liderado por índios.

Se Valle exibia o que Gramsci define como "conscientização contraditória" de grupos subalternos - abraçando uma essência indígena consagrada pelas elites, desprezando os brancos enquanto procura sua assistência - vários fatores explicam tal comportamento ${ }^{75}$. Em primeiro lugar, o Estado Novo enviou sinais contraditórios aos povos indígenas. Políticas protecionistas endossadas pelo regime foram burladas pela prática social. O índio perfeito louvado por ideólogos foi uma criação que uniu o bom selvagem ao brasileiro genérico. Sobretudo, as co rrelações de força na sociedade brasileira circunscreviam opções de índios tais como Valle. Sem o domínio territorial e a autonomia dos Xavante, tais índios "competentes e civilizados" tentaram fazer o máximo de um projeto govemamental ambígüo. Uma vez despidos da sua capa protetora, índios como os Xavante e vários outros na região Amazônica seriam forçados a seguir uma estratégia similar. E assim o fizeram.

\section{NOTAS}

${ }^{1} \mathrm{O}$ autor deseja agradecer a Emília Viotti da Costa, Gil Joseph, Jeff Lesser e Vivian Flanzer por suas valiosas observações e sugestões na elaboração deste artigo, originalmente publicado no Journal of Latin American Studies, no 29, 1997, pp. 747-768.

${ }^{2}$ CORRIGAN, P. e SAYER, D. The Great Arch: English State Formation as Cultural Revolu tion. Oxford, 1985.

${ }^{3}$ Para um relato celebratório das origens e objetivos do SPI - se não necessariamente de seus sucessos - ver RIBEIRO, D., Os Índios e a Civilização. Rio de Janeiro, Civilização Brasileira, 1970. Para uma análise revisionista inspirada em Foucault, que enfatiza o papel repressivo do Estado ao controlar questões indígenas, ver LIMA, A. C. de Souza. Um grande cerco de paz: poder tutelar, indianidade e formação do Estado no Brasil. Petrópolis, Vozes, 1995.

${ }^{4}$ No decorrer deste artigo, utilizo o termo "índio" tal como definido na legislação brasileira, para se referir a um indivíduo que é descendente de povos pré-colombianos e que se identifica e é identificado como pertencendo a um grupo étnico cujas características culturais são distintas da sociedade nacional. Utilizo o termo "branco" tal como é popularmente empregado no contexto das relações interétnicas brasileiras, para se referir a todos os não-índios.

${ }^{5}$ Departamento de Imprensa e Propaganda. Rumo ao Oeste(n.d.), p. 04. Sobre o DIP ver CARONE. O Estado Novo (1937-45). São Paulo, Difel,1997, pp. 169-172. 
${ }^{6}$ A fotografia de Vargas segurando um bebê Karajá foi distribuida aos postos indígenas por todo o Brasil. Ver Serviço de Proteção aos Índios (SPI) Boletim 20, jul. 1943, p. 196.

${ }^{7}$ Instituto Brasileiro de Geografia e Estatística. Goiânia. Rio de Janeiro, 1942, p. 01.

${ }^{8}$ Otávio Velho argumenta que a Marcha serviu para evitar a reforma estrutural do coronelismo nas áreas rurais brasileiras. Ver VELHO. Capitalismo autoritário e campesinato. São Paulo, Difel, 1976, pp. 148-151. De modo similar, Alcir Lenharo aponta que a Marcha, com sua retórica e ostentação, criou um sentimento ilusório de participação política popular numa sociedade marcada por um regime ditatorial. Ver LENHARO. Colonização e trabalho no Brasil: Amazônia, Nordeste e Centro-Oeste - os anos 30. Campinas, Papirus, 1986.

${ }^{9}$ Ver LENHARO. Sacralização da Política. Campinas, Papirus 1986, pp. 53-73.

${ }^{10}$ De acordo com o relatório anual do SPI de 1954, o orçamento anual da agência entre 1910 e 1930 variava (com reajustes em cruzeiros) desde a quantia mínima de CR\$300.000 (1915) até a quantia máxima de CR $\$ 3.880 .000$ (1930). A média variava em torno de CR $\$ 1.000 .000$. Em 1931 o orçamento caiu para CR\$1.560.000, caindo para menos de um milhão em 1940, mas aumentando constantemente de 1941 a 1944, quando atingiu CR\$3.703.000. SPI, Relatório das Atividades do Serviço de Proteção aos Índios durante o ano de 1954. Rio de Janeiro, 1954, p. 117.

${ }^{11}$ Para uma discussão mais completa sobre as origens e trajetórias do CNPI, ver FREIRE, C.A. da Rocha. Indigenismo e Antropologia - O Conselho Nacional de Proteção aos Índios na Gestão Rondon (1939-55) , Dissertação de Mestrado, UFRJ-Museu Nacional, 1990.

${ }^{12}$ RONDON, Cândido Mariano da Silva. Rumo ao Oeste: Conferência Realizada Pelo Gene ral Rondon no D.I.P. em 3-IX-40 e discursos do Dr. Ivan Lins e do General Rondon, pro nunciados na Associação Brasileira de Educação. Rio de Janeiro, 1940, pp. 21-22.

${ }^{13}$ Sobre invenções de tradições pelo governo para naturalizar processos e relações sociais, ver HOBSBAWM, Eric J. and RANGER, Terence. (eds.). The Invention of Tradition. Cambridge University Press, 1983.

${ }^{14}$ Ver HEMMING, J. Red Gold: The Conquest of Brazilian Indians, 1500-1760. Cambridge University Press, 1978, pp. 292-311.

${ }^{15}$ Ao colocar os índios no centro das representações do Oeste, a tática de Rondon se diferia da imagem do índio no discurso dos EUA sobre a colonização do Oeste americano no fim do século XIX. Richard White focaliza as duas principais imagens empregadas. A tese clássica de Frederick Jackson Turner sobre a fronteira dos EUA marginalizou os indios da história da colonização do oeste americano. Bufalo Bill, por outro lado, estigmatizou os povos indígenas como selvagens sanguinários. Ver WHITE. "Frederick Jackson Turner and Buffalo Bill”. In GROSSMAN, James, (ed.). The Frontier in American Cultur e. Berkeley, 1994, pp. 06-65.

${ }^{16}$ Ver LIMA, A.C. de Souza. "A identificação como categoria histórica”. In OLIVEIRA, João Pacheco de, (ed.). Os poderes e as terras dos Índios Rio de Janeiro, s.n., 1989, pp. 139-197.

${ }^{17}$ SPI, "Memórias sobre as causas determinantes da diminuição das populações indígenas do Brasil". Paper apresentado no IX Congresso Brasileiro de Geografia, 29 de Julho, 1940, p. 02. Fundação Nacional do Índio (Brasília) Documentação SPI/Documentos Diversos.

${ }^{18}$ Vasconcelos, citado no Departamento Administrativo do Serviço Público (DASP). Revista do Serviço Público, vol. 03, nos 1-2, jul.-ago. 1939, p. 34. 
${ }^{19}$ MAGALHÃES, A. Couto de. Encantos do Oeste. Rio de Janeiro, Imprensa Nacional, 1945, p. 42.

${ }^{20}$ CORDEIRO, F. de Bastos. Brasilidades. Rio de Janeiro,Niemeyer, 1943.

${ }^{21}$ FRANCO, A. Arinos de Mello. O Índio Brasileiro e a Revolução Francesa. Rio de Janeiro, José Olympio, 1937.

${ }^{22}$ COSTA, A. Indiologia. Rio de Janeiro, Gráfica Laemmert, 1943, p. 13.

${ }^{23}$ Conselho Nacional de Proteção aos Índios (CNPI). 19 de Abril: O Dia do Índio - as Co memorações Realizadas em 1944 e 45 . Rio de Janeiro, 1946, passim.

${ }^{24}$ Os historiadores do Estado Novo enfatizaram uma manipulação ideológica similar na repressão contra os imigrantes alemães, por presumirem sua simpatia ao regime nazista. Os governantes falavam de uma "nacionalidade brasileira" ameaçada de destruição por um grupo étnico subversivo; na realidade, a construção de uma "nacionalidade brasileira" era fundamentada na eliminação das distinções étnicas. Ver SCHWARTZMAN, S.; BOUSQUET BOMENY, H M. e COSTA, V.M. Ribeiro. Tempos de Capanema. Rio de Janeiro, Paz e Terra, 1984. $\mathrm{O}$ caso dos índios difere do imigrante alemão, no entanto, pelo fato de que a maioria das publicações e pronunciamentos governamentais não retratava o índio como um inimigo, mas como um ícone.

${ }^{25}$ Para uma discussão mais completa sobre a relação entre o indigenismo mexicano e as políticas do governo brasileiro ver FREIRE. op. cit., pp. 57-68.

${ }^{26}$ ARTIAGA, Z. Dos Índios do Brasil Central. Uberaba,Triângulo, n.d., pp. 13-26.

${ }^{27}$ Oswaldo Aranha, no prefácio da tradução brasileira de PADILHA, E. O homem livre da America . Trad. Fernando Tudé de Souza, Rio de Janeiro, 1943. Como o título sugere, o livro de Padilla era uma homenagem ao pan-americanismo.

${ }^{28}$ O Dia, Abril 1945, p. 15.

${ }^{29}$ CNPI, 19 de abril , pp. 39-41.

${ }^{30}$ BRO OKSHAW, D. Paradise Betrayed: Brazilian Literature of the Indian. Amsterdam, 1988, p.75.

${ }^{31}$ GONZALEZ, M e TREECE, D. The Gathering of Voices: TheTwentieth-Century Poetry of Latin America. London, 1992, pp. 96-101. Para uma discussão sobre a adoção do "primitivismo" por intelectuais brasileiros - e suas influências européias - durante a Semana de Arte Moderna, ver JACKSON, K.D. A prosa vanguardista na literatura brasileira: Oswald de Andrade. São Paulo, Perspectiva, 1978, pp. 09-18.

${ }^{32} \mathrm{O}$ símbolo do movimento Verdeamarelo era o curupira, o protetor Tupi-guarani do sertão. Ver VASCONCELOS, G. Ideologia Curupira: Análise do Discurso Integralista. São Paulo, Brasiliense,1979, p. 20.

${ }^{33}$ FREYRE, G. The Masters and Slaves. Berkeley, 1986, pp. 81-184.

${ }^{34}$ De fato, o Estado Novo não só foi influenciado pelos movimentos ideológicos dos anos 20, como incorporou alguns de seus intelectuais mais proeminentes (de todas as correntes políticas) no regime. Ver OLIVEIRA, L. Lippi; VELLOSO, M. Pimenta e GOMES, A. Castro. Estado Novo, Ideologia e Poder.Rio de Janeiro, Zahar, 1982, pp. 10-11.

${ }^{35}$ COSTA. op. cit., p. 11.

${ }^{36}$ Para uma discussão sobre a adesão seletiva das elites brasileiras do século XIX às idéias li- 
berais européias, ver COSTA, E. Viotti da. The Brazilian Empire: Myth and Histories. Chicago University Press, 1985, pp. 53-77 e SHCWARTZ, R. Misplaced ideas: Essays on Brazilian Culture. Londres, 1992, pp.19-31.

${ }^{37}$ SKID MORE. Black into White: Race and Nationality in Brazilian Thought. Durham, 1993, pp. 205-207. Skidmore observa os manifestos de doze intelectuais brasileiros proeminentes contra o racismo e em 1942 pela Associação Brasileira de Antropologia e Etnologia.

${ }^{38}$ Os eugenistas brasileiros, com o mostra Stepan, rejeitam as noções de supremacia racial e abraçam a fé lamarckiana no aperfeiçoamento através da mudança ambiental. Ver STEPAN, N. Leys. "The Hour of Eugenics: Race, Gender and Nation in Latin America". Ithaca, 1991.

${ }^{39}$ SPI, "Memória sobre as causas", pp. 01-02.

${ }^{40}$ PINTO , E. Roquette. "Contribuição a antropologia do Brasil". In Revista de Imigração e Colonização , vol I, noํ0, jul. 1940, p. 440.

${ }^{41}$ Ver, por exemplo, PADILHA, Leão. O Brasil na posse de si mesmo. Rio de Janeiro, Gráfica Olímpica, 1941. Para análises históricas sobre políticas imigratórias durante a Era Vargas, que tinha por objetivo evitar um grupo "indesejável", os judeus, ver LESSER, J. Welcoming the Undesirables. Berkeley, 1994 e CARNEIRO, M. L. O anti-semitismo na era Vargas (19301945). São Paulo, Brasiliense, 1988. O tratamento diferencial dado pelos intelectuais brasileiros aos índios em relação a outros grupos "não-europeus", é talvez mais fortemente revelado no trabalho de Afonso Arinos de Mello Franco. O mesmo autor que celebrou a herança indígena brasileira e as contribuições para a civilização o cidental também escreveu o antisemita Preparação ao nacionalsimo: Cartas aos que têm vinte anos. Rio de Janeiro, Civilização Brasileira, 1934, que opunha a entrada de judeus no Brasil.

${ }^{42}$ CNPI, Relatório. Rio de Janeiro, 1946, p. 54.

${ }^{43}$ Relatório do Diretor do SPI, Coronel Vicente de Paulo Teixeira da Fonseca Vasconcelos (1940?). Museu do Índio, Rio de Janeiro, Setor de Documentação (MI/SEDOC) Filme 237/Fot 1237-1273.

${ }^{44}$ LYRA, João. "Raça, educação e desporto”. In Estudos e Conferências. no 14, dez. 1941, p. 32.

${ }^{45}$ BARROS, Olegário Moreira de. "Rondon e o Índio". In Revista do Instituto Histórico de Mato Grosso, vol. 22, nํs 43-44, 1940, p. 17. Para uma discussão sobre o projeto de educação física do Estado Novo para forjar cidadãos robustos, ver CARNEIRO, op. cit., pp.139142.

${ }^{46}$ Revista de Imigração e Colonização. vol. I no 02, abr. 1940, p. 207.

${ }^{47}$ SPI, "Memória sobre as causas", p. 29.

${ }^{48}$ DASP, Revista do Serviço Público.vol. 03, nº 03, set. 1943, p. 84.

${ }^{49}$ Para uma discussão sobre a relação conflituosa entre índios e o Estado-nação, ver URBAN, G. e SHERZER, J. "Introduction: Indians, Nation-States, and Culture". In URBAN, Greg e SHERZER, Joel (eds.). Nation States and Indians in Latin America. Austin, 1991, pp. 01-18; e DURHAM, E. Ribeiro. “O lugar do índio”. In Comissão Pró-Índio/SP, O Índio e a Cidada nia. São Paulo, Brasiliense, 1983, pp. 11-19.

${ }^{50}$ BRASIL, T. Paes de Souza. Íncolas Selvícolas. Rio de Janeiro, 1937, pp.65-69.

${ }^{51}$ ESCOBAR, I. A Marcha para o O este: Couto Magalhães e Getúlio Vargas. Rio de Janeiro, 1941, p. 116. 
${ }^{52}$ Sobre o período colonial, ver PERRONE-MOISÉS, B. "Índios Livres e Índios Escravos: Os Princípios da Legislação Indigenista do Período Colonial (Séculos XVI-XVIII)". In CUNHA, Manuela Carneiro da (ed.). História dos Índios no Brasil. São Paulo, Companhia das Letras, 1992, pp. 115-132; sobre a dicotomia do século XIX entre o Tupi "pacífico" e o Tapuia "feroz", ver CUNHA, M. Carneiro da. "Prólogo". In CUNHA, Manuela Carneiro da (ed.). Legis lação Indigenista no Século XIX: Uma Compilação 1808-1889. São Paulo, EDUSP, 1992, pp. 07-08.

${ }^{53}$ Ver BERKHOFERJR, R.F. The White Man's Indian: Images of the American Indian fr om Columbus to the Present. New York, 1978.

${ }^{54}$ Tucci Carneiro fornece uma extensa revisão sobre os pensadores brasilerios influenciados por teorias racistas européias que estigmatizavam os índios, negros e mestiços. Ver CARNEIRO, Tucci. op. cit., pp. 83-154.

${ }^{55}$ Sobre a escravidão de índios inimigos durante o período colonial, ver PERRONE-MOISÉS. op. cit., pp. 123-128.

${ }^{56} \mathrm{O}$ tema do índio corrompido pelo branco mau, comum nas publicações do SPI durante este período, seria reiterado por MARÇAL, Heitor. Moral Ameríndia. Rio de Janeiro, Imprensa Nacional, 1946, um texto publicado pelo Ministério da Educação e Saúde.

${ }^{57} \mathrm{RONDON}$, J. O Índio como sentinela das nossas fronteiras. Rio de Janeiro, Imprensa Nacional, 1944, p. 34.

${ }^{58}$ PAULA, J.M. de. Terra dos Índios. Rio de Janeiro, 1944, pp.90-91.

${ }^{59}$ Para um exame sobre como o governo Vargas engajou a classe trabalhadora, ver GOMES, A. de Castro. A Invenção do trabalhismo. Rio de Janeiro, IUPERJ, 1994, p. 185.

${ }^{60}$ Ver OLIVEIRA FILHO, J. Pacheco de.'O Nosso Governo': os Ticuna e o Regime Tutelar São Paulo, Marco Zero, 1988, pp. 176-192. Sobre a assistência do SPI aos Mundurukú, ver ARNAUD, E. O Índio e a expansão nacional. Belém, CEJUP, 1989, p. 203-255.

${ }^{61}$ SPI, Relatório, (1939), p. 03.

${ }^{62}$ ROSEBERRY, W. "Hegemony and the Language of Contention". In JOSEPH, Gilbert M. and NUGENT, Daniel (eds.). Everyday Forms of State Formation: Revolution and the Negotia tion of Rule in Modern Mexico. Durham, 1994, p. 361.

${ }^{63}$ Ver SILVA, A. Lopes da. "Dois Séculos e meio de História Xavante”. In Histónia dos Indios no Brasil. pp. 362-365.

${ }^{64}$ MAYBURY-LEWIS, D. Akwe-Shavante Society. New York, 1974, p. 02.

${ }^{65}$ Idem, pp. 167-170. Ver também GIACCARIA, B. e HEIDE, A. Xavante (aúwe Uptabi: Povo Autêntico). São Paulo, Dom Bosco, 1972, pp. 36-43.

${ }^{66}$ A Noite, 24 Agosto 1944, p. 01.

${ }^{67}$ SOUZA, L. de. Os Xavante e a Civilização. Rio de Janeiro, 1953, p. 31.

${ }^{68}$ MAYBURY-LEWIS. op. cit., p. 05.

${ }^{69}$ RONDON, citado A Noite, 16 de Novembro 1941, p. 01.

${ }^{70}$ Sobre a ecologia do Brasil Central e as adaptações dos Xavante a ela, ver FLOWERS, N. "Forager-Farmers: The Xavante Indians of Central Brazil". Tese de doutorado, City University of New York, 1983.

${ }^{71}$ NIMUENDAJU, C. The Serente. Los Angeles, 1942, p. 08. 
${ }^{72}$ Carta de Lírio Arlindo do Valle para Getúlio Vargas, Rio de Janeiro, Setembro de 1945. MISEDOC, Documentos Avulsos.

${ }^{73}$ Para um resumo biográfico de Poti, ver ALMEIDA, Geraldo Gustavo de. Heróis Indígenas do Brasil. Rio de Janeiro, 1988, pp. 105-106.

${ }^{74}$ Para maiores discussões sobre a natureza contraditória da cultura popular ver JOSEPH, G. e NUGENT, D. "Popular Culture and State Formation". In Everyday Forms of State Formation: Revolution and the Negotiation of Rule in Modem Mexico. Durham, 1994, pp. 21-22.

${ }^{75}$ GRAMSCI, Antonio. Selections from the Prison Notebooks.Trad. Geoffrey Nowell Smith, New York, 1971, p. 333. 